\title{
Note on the Front Cover Image
}

Tn 2011, the Turkish researcher of Ottoman printing history Yahya Erdem Lublished the image of an engraving depicting the Müteferrika Press. ${ }^{1}$ According to the author, the engraving is found in a German book of the 1750s whose title he has not written down because of "negligence" ("gaflet eseri," in the author's words). Since-according to him-the image has never been reprinted before, no one has referred to it, and it is not available on the Internet, the author claims that, until someone finds the real source of this image, everyone who reprints it should refer to his article as the only source. Otherwise such a reprint would be considered plagiarism (since the latter is a copyright infringement, it is amazing that someone could claim this if he does not really hold the copyright!).

It should be noted that Yahya Erdem's publication is indeed very important, since for the first time ever a scholarly study draws attention to the only known and the earliest so far image of the Müteferrika Press. However, I found a reproduction of the same engraving even in an earlier publication, and on page 835 of Andreas Lazarus von Imhof's book published in 1735 (see fig. 1). ${ }^{2}$ The digital copy of Imhof's book is available online for free within Google's digitization project of books with no copyright. ${ }^{3}$ Thus, Imhof's case shows that the said engraving has been reprinted at least twice, and the earliest known reprint (of 1735) is even contemporary of the Müteferrika Press itself, which operated between 1726 and 1746.

The image reprinted on the front cover of this book is the one appearing on page 835 of Imhof's book (1735), and not that printed in the 1750s and reprinted by Yahya Erdem in 2011.

1 Yahya Erdem, "Müteferrika Matbaasının Erken Dönemde Yapılmış Bilinmeyen Bir Resmi," Müteferrika 39 (2011): 222.

2 Andreas Lazarus von Imhof, Des Neu-eröffneten historischen Bilder-Saals, vol. 9, part 1 (Nuremberg: Johann Leonhard Buggel and Johann Andreas Seitz, 1735), 835.

3 https://books.google.bg/books?id=sYBNAAAAcAAJ\&pg=PA835\# $\mathrm{v}=$ onepage\&q\&f=false. 